\title{
COVID-19 en verwikkelingen vaccinatie: beroepsziekte, arbeidsongeval?
}

Marc Vandeweerdt

In België hebben werknemers recht op vergoeding voor schade door arbeidsongeval of beroepsziekte. Er zijn aparte regelingen voor werknemers in de privésector en voor overheidspersoneel, maar de verschillen tussen beide zijn van weinig belang voor wat volgt.

De discussie over het onderscheid tussen arbeidsongeval en beroepsziekte werd in het Belgisch parlement al gevoerd bij de voorbereiding van de eerste arbeidsongevallenwet (1903). De werkgevers waren bereid schade door arbeidsongevallen (gedeeltelijk) voor hun rekening te nemen, maar zij weigerden dat pertinent voor schade door beroepsziekten. De beroepsziekteverzekering zou uiteindelijk (1927) worden toevertrouwd aan een overheidsinstelling. Vandaag is dat het Federaal agentschap voor beroepsrisico's (Fedris), dat gefinancierd wordt vanuit sociale bijdragen. De arbeidsongevallenverzekering wordt nog steeds uitgevoerd door particuliere verzekeringsondernemingen, waaraan de werkgevers premies betalen in verhouding tot het verzekerde risico.

Het beslissende criterium om het onderscheid te maken tussen arbeidsongeval en beroepsziekte, ligt in de duur van de oorzakelijke feiten (kader 1). Is de gezondheidsschade te wijten aan een plotselinge gebeurtenis, dan gaat het om een ongeval. Is de schade echter het gevolg van een langdurige blootstelling aan een schadelijk agens, dan gaat het om een beroepsziekte.

\section{Kader 1}

'Een ongeval is eene plotselinge, ongewone gebeurtenis, en onderstelt plotselinge inwerking eener uiterlijke kracht. Er is, in onderhavig geval, geen spraak van bestendige en gewone feiten, voortdurende of

Dr. Marc Vandeweerdt werkt als medisch adviseur bij Fedris, het Federaal agentschap

voor beroepsrisico's, en is gastdocent aan de KU Leuven.

Correspondentieadres: marc.vandeweerdt@kuleuven.be gewone oorzaken van een kwaad, en afhangend van de geregelde uitoefening van een bedrijf; die oorzaken zijn, bij voorbeeld, uitwasemingen of stof, waarvan de werkman gewoonlijk den schadelijken invloed, als gevolg van den arbeid of uitwerksel van het midden ondergaat. Die oorzaken verwekken niet het ongeval, maar de bedrijfsziekte...' (Verslag aan de Kamer van Volksvertegenwoordigers, uitgebracht door de heer Van Cleemputte, zitting 1901-1902, nr. 302, 106-107.)

\section{Weinig animo om infectieziekte als arbeidsongeval te zien}

Infectieziekten zijn altijd een bron van discussie geweest. Er bestaat wel degelijk een verband tussen de duur van de blootstelling aan potentiële infectiebronnen en de kans om een infectie op te lopen, maar de besmetting die de ziekte werkelijk veroorzaakt is typisch het gevolg van een eerder kortstondig contact met een infectiebron. De arbeidsongevallenwet kent een (weerlegbaar) vermoeden van oorzakelijk verband tussen plotselinge gebeurtenis en gezondheidsschade. In principe vormt elk contact met een infectieus persoon een plotselinge gebeurtenis en zou dat als oorzaak van de ziekte kunnen worden ingeroepen. Toch blijkt er weinig animo te bestaan om de erkenning van COVID-19 als arbeidsongeval af te dwingen.

\section{COVID-19 in de beroepsziekteverzekering}

COVID-19 stond als zodanig uiteraard niet in de beroepsziektelijst, maar kwam er toch in voor. Naast een aantal precies omschreven infectieziekten (tuberculose, virale hepatitis) werd lang geleden immers een restcategorie van 'andere infectieziekten' aan de lijst toegevoegd (ziektecode 1.404.03, kader 3). Wie een ziekte uit de lijst vertoont en werd blootgesteld aan het beroepsrisico van die ziekte (zoals in de wet omschreven: kader 2), heeft recht op schadeloosstelling. Hij hoeft het oorzakelijk verband tussen beide niet te bewijzen.

De erkenning van COVID-19 op basis van ziektecode 1.404 .03 is echter beperkt tot mensen die werkzaam 


\section{Kader 2}

Er is een beroepsrisico ... indien de blootstelling aan de schadelijke invloed inherent is aan de beroepsuitoefening en beduidend groter is dan de blootstelling van de bevolking in het algemeen, en indien deze blootstelling, volgens algemeen aanvaarde medische inzichten, in groepen van blootgestelde personen de overwegende oorzaak van de ziekte vormt. (Artikel 32, tweede lid, van de beroepsziektewet)

zijn in de gezondheidszorg. Weliswaar kunnen ook ziekten (of beroepsgroepen) die niet in de lijst zijn opgenomen in aanmerking komen voor vergoeding, maar dan moet de getroffene effectief bewijzen dat hij zijn ziekte door het werk heeft opgelopen. Voor COVID-19 is dat meestal onmogelijk. En mocht men het toch kunnen bewijzen, dan is impliciet het bewijs van een plotselinge gebeurtenis geleverd en gaat het zeker om een arbeidsongeval.

Tijdens de strenge lockdown van 18 maart tot 17 mei 2020 moesten, mochten of konden tal van werknemers hun dagen thuis doorbrengen. Zo vermeden zij het risico vanwege contacten met collega's of cliënteel. Anderen, met name degenen die werkzaam waren in cruciale sectoren en essentiële diensten en niet konden telewerken, moesten dat risico wel ondergaan. Op grond van die overweging werden die activiteiten voor de duur van die lockdown als een beroepsrisico beschouwd en werd een specifieke omschrijving in de beroepsziektelijst opgenomen (ziektecode 1.404.04; kader 3)

\section{Kader 3}

1.404.03 Andere infectieziekten bij de leden van het personeel dat werkzaam is op het gebied van de preventieve gezondheidszorg, geneeskundige verzorging, verpleging aan huis of laboratoriumwerk en andere professionele activiteiten in verzorgingsinstellingen waar een verhoogd infectierisico bestaat. 1.404.04 Elke ziekte veroorzaakt door SARS-CoV-2 bij werknemers die in de periode van 18 maart 2020 tot en met 17 mei 2020 beroepsactiviteiten hebben uitgeoefend in bedrijven van de cruciale sectoren en de essentiële diensten zoals bedoeld in de bijlage van het ministerieel besluit van 23 maart 2020 houdende dringende maatregelen om de verspreiding van het coronavirus COVID-19 te beperken, voor zover het optreden van de ziekte wordt vastgesteld in de periode van 20 maart 2020 tot en met 31 mei 2020. (Blootstellingscriteria werden bij koninklijk besluit vastgesteld.

\section{Verband tussen beroep en risico op COVID-19}

De beroepsziektewet vereist een blootstelling aan het beroepsrisico van de ziekte, wat op zijn minst betekent dat de kans om de ziekte door het werk op te lopen beduidend groter is dan daarbuiten.

COVID-19 is een hoogst besmettelijke ziekte waartegen niemand antistoffen had. Zonder vaccin zou mettertijd iedereen de ziekte krijgen. Wie heeft er dan een beroepsziekte? Anderzijds: in bepaalde beroepen is er, alleszins tijdelijk, een duidelijk verhoogd risico (geweest). Toch blijkt het beroep doorgaans niet de belangrijkste determinant van het risico te zijn. De grote verschillen tussen Europese landen en tussen regio's binnen eenzelfde land, kunnen daardoor niet verklaard worden. Andere (gedrags-) factoren zijn doorslaggevend.

Vrijwel alle studies tonen tijdens de beruchte eerste golf een sterk verhoogde incidentie bij gezondheidswerkers: het ging om een nieuwe infectieziekte, het infectierisico kon niet meteen correct worden ingeschat, testen en adequate beschermingsmiddelen waren niet of onvoldoende beschikbaar. Tijdens de tweede golf was de toestand helemaal anders.

Eind december 2020 rapporteerde Sciensano, de Belgische wetenschappelijk instelling voor gezondheidsbeleid, dat de prevalentie van antistoffen bij bloeddonoren was opgelopen tot 14,4 procent en bij gezondheidswerkers in ziekenhuizen tot 16,8 procent. $^{2}$

In een recenter rapport werd een poging gedaan om voor België de incidentie van de ziekte tijdens de tweede golf vast te stellen in elk van de 'secties' van de Economische activiteitennomenclatuur (NACE). ${ }^{3}$ Ondanks de beperkingen van dit onderzoek, die in het rapport worden besproken, blijkt dat er in de onderzochte periode wellicht nog altijd een verhoogd risico was in de sectie 'Menselijke gezondheidszorg en maatschappelijke dienstverlening' (figuur 2 uit het rapport). Op een gedeelde tweede plaats volgen 'Openbaar bestuur en defensie; verplichte sociale verzekeringen' (met daaronder het personeel van politie, brandweer en gevangeniswezen) en 'Onderwijs'. Spijtig genoeg zijn er geen data beschikbaar voor de lagere echelons van de NACE (afdelingen, groepen, klassen).

\section{Aangifte van beroepsziekten door de bedrijfsarts}

De bedrijfsarts is verplicht bij de Federale overheidsdienst Werkgelegenheid, Arbeid en Sociaal overleg en bij Fedris aangifte te doen van alle gevallen van beroepsziekte of vermoedelijke beroepsziekte waarvan hij of zij kennis heeft. Fedris zal de betrokkene dan voorstellen een aanvraag tot schadeloosstelling in te dienen. Als die aanvraag binnen 120 dagen volgt, geldt de datum van aangifte als datum van aanvraag. Dat is in het voordeel van de getroffene, omdat de 


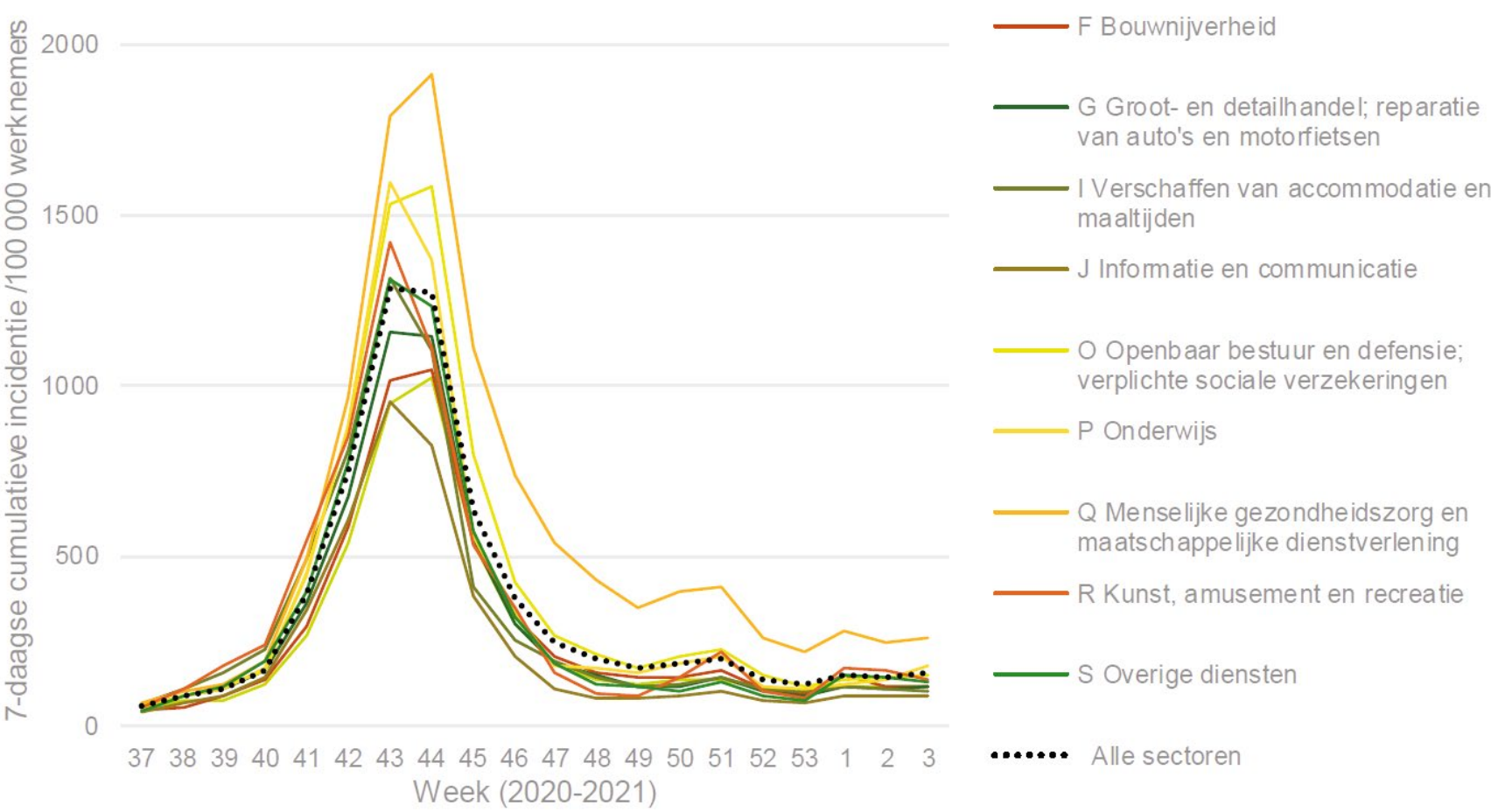

Figuur 2. Wekelijkse COVID-19 incidentie (cumulatief over 7 dagen) per 100.000 werknemers per sector, 08/09/2020 tot 26/01/2021, België. (Bron: RSZ-dataset over incidentie onder werknemers per sector).

aanvraagdatum het tijdstip bepaalt waarop de vergoedingen kunnen ingaan. Overigens kan iedereen uit eigen beweging een aanvraag tot schadeloosstelling indienen.

De cijfers in Tabel 1 spreken voor zich. Vrijwel alle aangiften $(98,6 \%)$ betreffen gezondheidswerkers.

\section{Tabel 1.}

\begin{tabular}{|l|r|r|r|}
\hline $\begin{array}{l}\text { Jaar van } \\
\text { aangifte }\end{array}$ & Mannen & Vrouwen & \multicolumn{1}{l|}{ Totaal } \\
\hline 2020 & 2.532 & 13.032 & 15.564 \\
\hline 2021 (tot 6 april) & 533 & 2.895 & 3.428 \\
\hline Totaal & 3.065 & 15.972 & 18.992 \\
\hline
\end{tabular}

\section{Aanvragen om schadeloosstelling en beslissingen}

De geregistreerde aanvragen zijn gevisualiseerd in Tabel 2:

Tabel 2.

\begin{tabular}{|l|c|c|c|}
\hline Aanvrager & $\mathbf{2 0 2 0}$ & $\begin{array}{c}\mathbf{2 0 2 1} \text { (tot } \\
\mathbf{6} \text { april) }\end{array}$ & Totaal \\
\hline $\begin{array}{l}\text { Getroffene (aanvraag } \\
\text { wegens ziekte) }\end{array}$ & 12.947 & 1.913 & 14.860 \\
\hline $\begin{array}{l}\text { Nabestaanden (aanvraag } \\
\text { wegens overlijden) }\end{array}$ & 16 & - & 16 \\
\hline
\end{tabular}

Op 6 april 2021 wachtten nog 2334 aanvragen op registratie. Op diezelfde datum waren er 5475 beslissingen genomen (Tabel 3).

Tabel 3.

\begin{tabular}{|l|r|r|}
\hline $\begin{array}{l}\text { Erkenning zonder } \\
\text { vergoeding TAO* }(<15 \\
\text { dagen) }\end{array}$ & 1.587 & $28,99 \%$ \\
\hline $\begin{array}{l}\text { Erkenning met vergoe- } \\
\text { ding TAO ( } \geq 15 \text { dagen) }\end{array}$ & 3.288 & $60,05 \%$ \\
\hline Erkenning overlijden & 8 & $0,15 \%$ \\
\hline Afwijzing & 592 & $10,81 \%$ \\
\hline Totaal & 5.475 & $100,00 \%$ \\
\hline
\end{tabular}

*TAO: tijdelijke arbeidsongeschiktheid; niet vergoedbaar indien minder dan 15 dagen

\section{En wat met verwikkelingen van COVID-19-vaccinatie?}

Verwikkelingen van een vaccinatie beantwoorden aan het begrip 'ongeval' van de arbeidsongevallenwet: er is een plotselinge gebeurtenis (de vaccinatie) en er is een letsel (de gezondheidsschade). Het gaat om een 'arbeidsongeval' wanneer er een verband bestaat tussen de vaccinatie en de uitvoering van de arbeidsovereenkomst. 
Of een bepaalde gezondheidsschade het gevolg is van een plotselinge gebeurtenis, is een medisch vraagstuk, maar het oorzakelijk verband wordt vermoed tot bewijs van het tegendeel. Ook de band met het werk (tijdens en door het feit van de uitvoering van de arbeidsovereenkomst) wordt ruim beoordeeld. Het ongeval moet niet noodzakelijk plaatsvinden gedurende de eigenlijke arbeidstijd. Het volstaat dat de werkgever enig gezag uitoefent over de werknemer, waardoor diens persoonlijke vrijheid wordt beperkt. Het ongeval moet in verband staan met de uitvoering van de arbeidsovereenkomst, maar moet niet noodzakelijk aan het werk te wijten zijn.

Dit wordt geillustreerd door twee uitspraken van het arbeidshof van Brussel. In het eerste arrest ${ }^{4}$ gaat het over een schoonmaakster in een ziekenhuis die in het kader van een vaccinatieprogramma, opgezet door de werkgever, wordt gevaccineerd tegen hepatitis B, waarna zij een facialisparalyse ontwikkelt die wordt toegeschreven aan de vaccinatie. De gebeurtenis deed zich voor tijdens en door het feit van de uitvoering van de arbeidsovereenkomst: omdat ze in een ziekenhuisomgeving werkte, aldus het arbeidshof, besloot haar werkgever haar te laten vaccineren tegen hepatitis B; zij nam niet zelf het initiatief.

Het tweede arrest ${ }^{5}$ betreft een werknemer die op de arbeidsplaats wordt gevaccineerd tegen griep. Deze inspuiting vormt volgens het arbeidshof een plotselinge gebeurtenis in de zin van de arbeidsongevallenwet. De vaccinatie werd aangeboden en georganiseerd door de werkgever, in het kader van de bevordering van de gezondheid op het werk. De vaccinatie werd derhalve verricht gedurende de uitoefening van de functie. Dat de vaccinatie niet verplicht was, is irrelevant.

Er kunnen in dit verband nog vele vragen worden gesteld. Hoe zit het met de normale en te verwachten neveneffecten van een vaccinatie? Wat als een gezondheidswerker zich buiten de werkuren op eigen initiatief laat vaccineren in een vaccinatiecentrum, opgezet door de overheid? We laten deze vragen rusten, maar gezien de ernstige nevenwerkingen die aan sommige vaccins worden toegeschreven, zullen ze vermoedelijk binnen afzienbare tijd in de rechtspraak opduiken.

\section{Referenties}

1. Karin Magnussen, Karin Nygard, Line Vold, Kjetil Telle. Occupational risk of COVID-19 in the 1st vs 2 nd wave of infection. Preprint https://doi. org/1101/2020.10.29.20220426

2. https://www.sciensano.be/nl/pershoek/aantal-bloeddonoren-en-gezondheidswerkers-met-antistoffen-tegen-coronavirus-stijgt

3. https://covid-19.sciensano.be/sites/default/files/Covid19/ Rapport\%20COVID-19\%20incidentie\%20in\%20de\%20actieve\%20beroepsbevolking_0.pdf

4. Arbh. Brussel 16 januari 2006, JTT 2006, 167-168.

5. Arbh. Brussel 21 november 2016, RGAR 2017, 15383. 